\section{Planting Depth Affects Survival, Root Growth, and Nutrient Content of Transplanted Pygmy Date Palms}

\author{
Timothy K. Broschat \\ University of Florida, Fort Lauderdale Research and Education Center, 3205 \\ College Avenue, Fort Lauderdale, FL 33314
}

Additional index words. Phoenix roebelenii, Mn deficiency

\begin{abstract}
Mature pygmy date palms (Phoenix roebelenii O'Brien) having a minimum of 90 cm of clear trunk were transplanted into a field nursery at their original depth or with 15 , 30,60 , or $90 \mathrm{~cm}$ of soil above the original rootball. Palms planted at the original level or with the visible portion of the root initiation zone buried had the largest canopies, highest survival rates, and lowest incidence of Mn deficiency 15 months after transplanting. Palms planted $90 \mathrm{~cm}$ deep had only a $40 \%$ survival rate, with small, Mn-deficient canopies on surviving palms. Palms whose original rootballs were planted $90 \mathrm{~cm}$ deep had very poor or no root growth at any level, but had elevated Fe levels in the foliage. None of the deeply planted palms produced any new adventitious roots higher than $15 \mathrm{~cm}$ above the visible portion of the root initiation zone.
\end{abstract}

Most mature palms can be successfully transplanted from one site to another, since new adventitious roots, which emerge from the root initiation zone at the base of the trunk, are produced throughout the life of the palm (Tomlinson, 1990). Visible evidence of this zone is often apparent on the bottom 15 to 30 $\mathrm{cm}$ of most palm trunks, and hidden root initials may exist slightly higher on the trunk. In old specimens of Phoenix L. spp. or Chamaedorea Willd. spp., visible root initials may extend $1 \mathrm{~m}$ or more up the trunk. These root initials do not normally develop into functional roots unless they are in contact with a moist substrate (Tomlinson, 1990).

In a fairly common, although controversial, practice, some landscapers plant mature palms deeper than they were originally growing to provide physical support for the palm and to achieve a uniform height among palms of differing original heights. Tall palms, such as Washingtonia robusta $\mathrm{H}$. Wendl., have been planted up to $6 \mathrm{~m}$ deep in California, but the long-term effects of this practice have never been studied. Unexplainable declines and death often occur years later in palms thus planted, and micronutrient deficiencies or wilts are often the most visible aboveground symptoms (Chase and Broschat, 1991). Proponents of this planting method argue that new adventitious roots emerge from the buried portion of the trunk to supplement or replace the original

Received for publication 28 Nov. 1994. Accepted for publication 17 Apr. 1995. Florida Agricultural Experiment Station Journal series no. R-04239. I thank SusanThor, Anita Durden, and Robert Jenkins for their technical assistance. The cost of publishing this paper was defrayed in part by the payment of page charges. Under postal regulations, this paper therefore must be hereby marked advertisement solely to indicate this fact.

HortScience, Vol. 30(5), August 1995 original rootball were counted on one side of each squared-off palm trunk.

Leaf samples were dried at $60 \mathrm{C}$, ground, and digested using a $\mathrm{H}_{2} \mathrm{SO}_{4}-\mathrm{H}_{2} \mathrm{O}_{2}$ method (Allen, 1974) modified for use in a microwave oven. Potassium, Mg, Fe, Mn, Zn, and $\mathrm{Cu}$ concentrations were determined using atomic absorption spectrophotometry. Regression analyses using linear and quadratic terms was performed on the raw data and $R^{2}$ (coefficient of multiple determination) values were presented.

\section{Results and Discussion}

More than half of the palms transplanted with rootballs $90 \mathrm{~cm}$ deep and $10 \%$ of the palms planted 30 or $60 \mathrm{~cm}$ deep died within 10 months from Mn deficiency (Table 1). None of the palms planted at the original depth $(0$ $\mathrm{cm}$ ) or $15 \mathrm{~cm}$ deep died from any cause. The number of leaves retained by the palms decreased as planting depth increased, and $\mathrm{Mn}$ deficiency severity increased with increasing planting depth (Table 1). Manganese-deficient $P$. roebelenii have small, thin, chlorotic new leaves with longitudinal necrotic streaks. As the deficiency progresses, new leaves emerge almost completely necrotic and frizzled in appearance. Death of the meristem quickly follows (Chase and Broschat, 1991).

The number of live roots within the original rootball was similar for palms planted from 0 to $60 \mathrm{~cm}$ deep, but was much less for palms planted $90 \mathrm{~cm}$ deep. The number of living roots emerging 0 to $15 \mathrm{~cm}$ above the original rootball was highest for palms planted $15 \mathrm{~cm}$ deep, but was slightly less for those planted 0,30 , or $60 \mathrm{~cm}$ deep and much less for those planted $90 \mathrm{~cm}$ deep (Table 1). Visible root initials were present on all palms up to 15 $\mathrm{cm}$ above the original soil surface at the time of transplanting, but since palms transplanted at the original level did not have moist soil in contact with these aerial roots, their further development was not as great as in palms having these root initials slightly buried. Although roots in the original rootball of palms planted $90 \mathrm{~cm}$ deep may have been occasionally inundated by a high water table, the roots 0 to $15 \mathrm{~cm}$ or higher above the original rootball in these palms remained well above the water table during most of this experiment. Still, their development was very poor compared to those on palms planted less deeply. This result suggested that soil $\mathrm{O}_{2}$ levels may be limiting or $\mathrm{CO}_{2}$ or other gas levels may be too high at this depth for good root growth (Kozlowski et al., 1991).

As expected, little development of roots occurred 15 to $30 \mathrm{~cm}$ above the soil line for palms transplanted at their original depth, yet few of these roots developed on palms having this portion of the trunk buried, either. No roots were observed $>30 \mathrm{~cm}$ above the original soil surface for palms in any treatment, suggesting that rooting in this species does not occur more than $\approx 15 \mathrm{~cm}$ above the visible portion of the root initiation zone.

Planting depth had little or no effect on leaf concentrations of $\mathrm{K}$ or $\mathrm{Cu}$, but did affect the 
Soll Management, Fertilization, \& Irrigation

uptake of $\mathrm{Mg}, \mathrm{Fe}, \mathrm{Mn}$, and Zn (Table 2). Foliar $\mathrm{Mg}$ and $\mathrm{Fe}$ concentrations remained relatively constant as planting depth was increased from 0 to $60 \mathrm{~cm}$, but were much higher for palms planted $90 \mathrm{~cm}$ deep. Reduced soil redox potentials in the vicinity of the water table should increase Fe solubility and may be responsible for the increased Fe uptake in palms surviving at this depth (Kozlowski et al., 1991). The reason for a similar response for $\mathrm{Mg}$ is not clear. Foliar $\mathrm{Zn}$ concentrations decreased slightly as planting depth was increased, possibly in response to reduced soil $\mathrm{O}_{2}$ levels, which may affect root respiration and nutrient uptake activity (Marschner, 1986).

Leaf Mn concentrations decreased consistently as planting depth increased (Table 2) and this was reflected in the increased severity of foliar Mn deficiency symptoms at greater depths (Table 1). Manganese deficiency was the primary micronutrient deficiency observed in this experiment, yet Chase and Broschat (1991) indicate that Fe deficiency is the most common visual manifestation of excessive planting depth in palms. The high levels of $\mathrm{Fe}$ in the soil, particularly near the water table, may be responsible for inhibiting Mn uptake in these palms, although reduced soil $\mathrm{O}_{2}$ levels may also be an important factor (Mortvedt et al., 1972).

In summary, planting pygmy date palms at the original depth or up to the top of the visible portion of the root initiation zone resulted in optimum survival and plant quality. As planting depth increased, survival decreased, Mn deficiency severity increased, and palm canopy size decreased. Palms planted $90 \mathrm{~cm}$ deep had poor survival rates and unacceptable Mn deficiency ratings and canopy size for those that did survive.

Table 1. Effects of planting depth on survival rate and number of leaves retained, Mn deficiency ratings, and root growth of surviving transplanted pygmy date palms. Data are treatment means \pm sE.

\begin{tabular}{|c|c|c|c|c|c|c|}
\hline \multirow[b]{2}{*}{$\begin{array}{l}\text { Depth } \\
(\mathrm{cm})\end{array}$} & \multicolumn{3}{|c|}{ Leaves } & \multicolumn{3}{|c|}{ No. living roots/tree } \\
\hline & $\begin{array}{c}\text { Dead } \\
\text { trees }(\%)\end{array}$ & $\begin{array}{c}\text { retained } \\
\text { (no.) }\end{array}$ & $\begin{array}{c}\mathrm{Mn} \\
\text { rating }^{\mathrm{z}}\end{array}$ & $\begin{array}{l}\text { Original } \\
\text { rootball }\end{array}$ & $\begin{array}{c}0-15 \mathrm{~cm} \\
\text { above }\end{array}$ & $\begin{array}{c}15-30 \mathrm{~cm} \\
\text { above }^{\mathrm{y}}\end{array}$ \\
\hline 0 & 0 & $46.6 \pm 2.6$ & $4.8 \pm 0.2$ & $31.7 \pm 3.6$ & $28.6 \pm 4.0$ & $0.3 \pm 0.3$ \\
\hline 15 & 0 & $47.8 \pm 3.3$ & $4.7 \pm 0.2$ & $32.9 \pm 3.7$ & $41.6 \pm 3.2$ & $4.8 \pm 2.6$ \\
\hline 30 & 10 & $38.9 \pm 2.6$ & $4.4 \pm 0.5$ & $26.2 \pm 2.8$ & $32.1 \pm 1.6$ & $5.2 \pm 2.7$ \\
\hline 60 & 10 & $36.0 \pm 2.6$ & $3.5 \pm 0.5$ & $34.8 \pm 8.6$ & $38.6 \pm 3.3$ & $8.7 \pm 3.6$ \\
\hline 90 & 60 & $8.3 \pm 3.7$ & $1.4 \pm 0.7$ & $7.4 \pm 6.5$ & $6.8 \pm 5.1$ & $0.0 \pm 0.0$ \\
\hline$R^{2}$ & $0.345^{* * *}$ & $0.556^{* * *}$ & $0.377^{* * *}$ & $0.108^{\mathrm{Ns}}$ & $0.396^{* * * *}$ & $0.201^{*}$ \\
\hline \multicolumn{7}{|l|}{ Significance } \\
\hline Linear & $* * *$ & $* * *$ & **** & & NS & NS \\
\hline Quadratic & $*$ & ** & NS & & **** & ** \\
\hline
\end{tabular}

${ }^{2} 0=$ dead, 3 = moderate deficiency, 5 = no deficiency symptoms.

y Original soil line.

Ns, *,*******Nonsignificant or significant at $P \leq 0.05,0.01$, or 0.001 , respectively.

Table 2. Effects of planting depth on leaf nutrient cation concentrations of surviving transplanted pygmy date palms. Data are treatment means \pm sE.

\begin{tabular}{|c|c|c|c|c|c|c|}
\hline $\begin{array}{l}\text { Depth } \\
\text { (cm) }\end{array}$ & $\begin{array}{c}\mathrm{K} \\
(\%)\end{array}$ & $\begin{array}{c}\mathrm{Mg} \\
(\mathrm{ppm})\end{array}$ & $\begin{array}{c}\mathrm{Fe} \\
(\mathrm{ppm})\end{array}$ & $\begin{array}{c}\mathrm{Mn} \\
(\mathrm{ppm})\end{array}$ & $\begin{array}{c}\mathrm{Zn} \\
(\mathrm{ppm})\end{array}$ & $\begin{array}{c}\mathrm{Cu} \\
(\mathrm{ppm})\end{array}$ \\
\hline 0 & $1.22 \pm 0.11$ & $1362 \pm 50$ & $140 \pm 3$ & $50.2 \pm 6.5$ & $36.5 \pm 0.4$ & $7.8 \pm 1.0$ \\
\hline 15 & $1.21 \pm 0.10$ & $1417 \pm 62$ & $150 \pm 4$ & $46.0 \pm 4.7$ & $36.8 \pm 0.5$ & $8.1 \pm 1.2$ \\
\hline 30 & $0.99 \pm 0.02$ & $1307 \pm 51$ & $152 \pm 5$ & $36.9 \pm 1.7$ & $34.9 \pm 0.6$ & $7.2 \pm 1.1$ \\
\hline 60 & $1.10 \pm 0.05$ & $1363 \pm 73$ & $146 \pm 4$ & $32.5 \pm 2.2$ & $34.8 \pm 0.8$ & $7.4 \pm 1.3$ \\
\hline 90 & $1.38 \pm 0.07$ & $1709 \pm 121$ & $191 \pm 26$ & $21.0 \pm 2.4$ & $34.7 \pm 0.6$ & $6.9 \pm 1.4$ \\
\hline$R^{2}$ & $0.164^{*}$ & $0.253^{* *}$ & $0.240^{* *}$ & $0.384^{* * *}$ & $0.187^{* *}$ & $0.081^{\mathrm{Ns}}$ \\
\hline \multicolumn{7}{|l|}{ Significance } \\
\hline Linear & NS & $* *$ & ** & $* * *$ & $* *$ & \\
\hline Quadratic & $* *$ & $* *$ & NS & NS & NS & \\
\hline
\end{tabular}

ss, ${ }^{* * *, * * *}$ Nonsignificant or significant at $P \leq 0.05,0.01$, or 0.001 , respectively.

\section{Literature Cited}

Allen, S.E. (ed.). 1974. Chemical analysis of ecological materials. Blackwell Scientific Publ., Oxford, England.

Chase, A.R. and T.K. Broschat. 1991. Diseases and disorders of ornamental palms. Amer. Phytopathol. Soc. Press, St. Paul, Minn.

Kozlowski, T.T., P.J. Kramer, and S.G. Pallardy (eds.). 1991. The physiological ecology of woody plants. Academic, San Diego.

Marschner, H. 1986. Mineral nutrition of higher plants. Academic, London.

Mortvedt, J.J., P.M. Giordano, and W.L. Lindsay (eds.). 1972. Micronutrients in agriculture. Soil Sci. Soc. Amer., Madison, Wis.

Tomlinson, P.B. 1990. The structural biology of palms. Clarendon Press, Oxford, England. 